\title{
REVIEW
}

\section{Endocrine and nutritional regulation of fetal adipose tissue development}

\author{
M E Symonds ${ }^{1}$, A Mostyn ${ }^{1,2}$, S Pearce $^{1}$, H Budge $^{1}$ and T Stephenson ${ }^{1}$ \\ ${ }^{1}$ Academic Division of Child Health, School of Human Development, University Hospital, Nottingham NG7 2UH, UK \\ ${ }^{2}$ Department of Agricultural Sciences, Imperial College London, Wye Campus, Wye, Ashford, Kent TN25 5AH, UK \\ (Requests for offprints should be addressed to M E Symonds; Email: Michael.Symonds@nottingham.ac.uk)
}

\begin{abstract}
In the fetus, adipose tissue comprises both brown and white adipocytes for which brown fat is characterised as possessing the unique uncoupling protein (UCP)1. The dual characteristics of fetal fat reflect its critical role at birth in providing lipid that is mobilised rapidly following activation of UCP1 upon cold exposure to the extrauterine environment. A key stage in the maturation of fetal fat is the gradual rise in the abundance of UCP1. For species with a mature hypothalamic-pituitary axis at birth there is a gradual increase in the amount and activity of UCP1 during late gestation, in conjunction with an increase in the plasma concentrations of catecholamines, thyroid hormones, cortisol, leptin and prolactin. These may act individually, or in combination, to promote UCP1 expression and, following the post-partum surge in each hormone, UCP1 abundance attains maximal amounts.
\end{abstract}

Adipose tissue grows in the fetus at a much lower rate than in the postnatal period. However, its growth is under marked nutritional constraints and, in contrast to many other fetal organs that are unaffected by nutritional manipulation, fat mass can be significantly altered by changes in maternal and, therefore, fetal nutrition. Fat deposition in the fetus is enhanced during late gestation following a previous period of nutrient restriction up to mid gestation. This is accompanied by increased mRNA abundance for the receptors of IGF-I and IGF-II. In contrast, increasing maternal nutrition in late gestation results in less adipose tissue deposition but enhanced UCP1 abundance. The pronounced nutritional sensitivity of fetal adipose tissue to both increased and decreased maternal nutrition may explain why the consequences of an adverse nutritional environment persist into later life. Journal of Endocrinology (2003) 179, 293-299

\section{Introduction}

Brown fat is characterised as possessing a unique uncoupling protein (UCP) 1 that when maximally activated is able to produce up to $300 \mathrm{~W} / \mathrm{kg}$ tissue of heat compared with 1-2 W/kg tissue by most other tissues (Power 1989). A primary function of fetal fat development, particularly in precocious thermoregulators, is to ensure that sufficient UCP1 is synthesised to enable effective thermoregulation following cold exposure to the extra-uterine environment (Clarke et al. 1997c). This adaptation is determined by the pre-partum development of the fetal endocrine mechanisms that ensure the maturation of a range of fetal organs for life after birth. The activation of UCP1 at birth is accompanied by a dramatic increase in lipolysis and mobilisation of lipids within fat depots (Power 1989) that also show white adipose tissue characteristics (Bispham et al. 2002). For both sheep and humans, brown fat is located primarily around the core organs and constitutes $2 \%$ of birth weight (Symonds \& Lomax 1992). Despite the relatively small amount of adipose tissue present in the fetus, its growth is under marked nutritional constraints. In contrast to many other fetal organs that are unaffected by nutritional manipulation, fat mass can be significantly altered by changes in maternal and, therefore, fetal nutrition (Budge et al. 2003). The present review will therefore consider the following critical aspects of fetal adipose tissue development:

1. The normal ontogenic development of the endocrine systems necessary for ensuring maximal UCP1 abundance around the time of birth.

2. Can specific endocrine stimulation of the fetus or newborn promote UCP1 abundance and thus mimic in part the endocrine stimulation that occurs around the time of birth?

3. The extent to which targeted nutritional manipulations may act to increase or decrease fetal fat deposition and the potential consequences for UCP1 function after birth. 


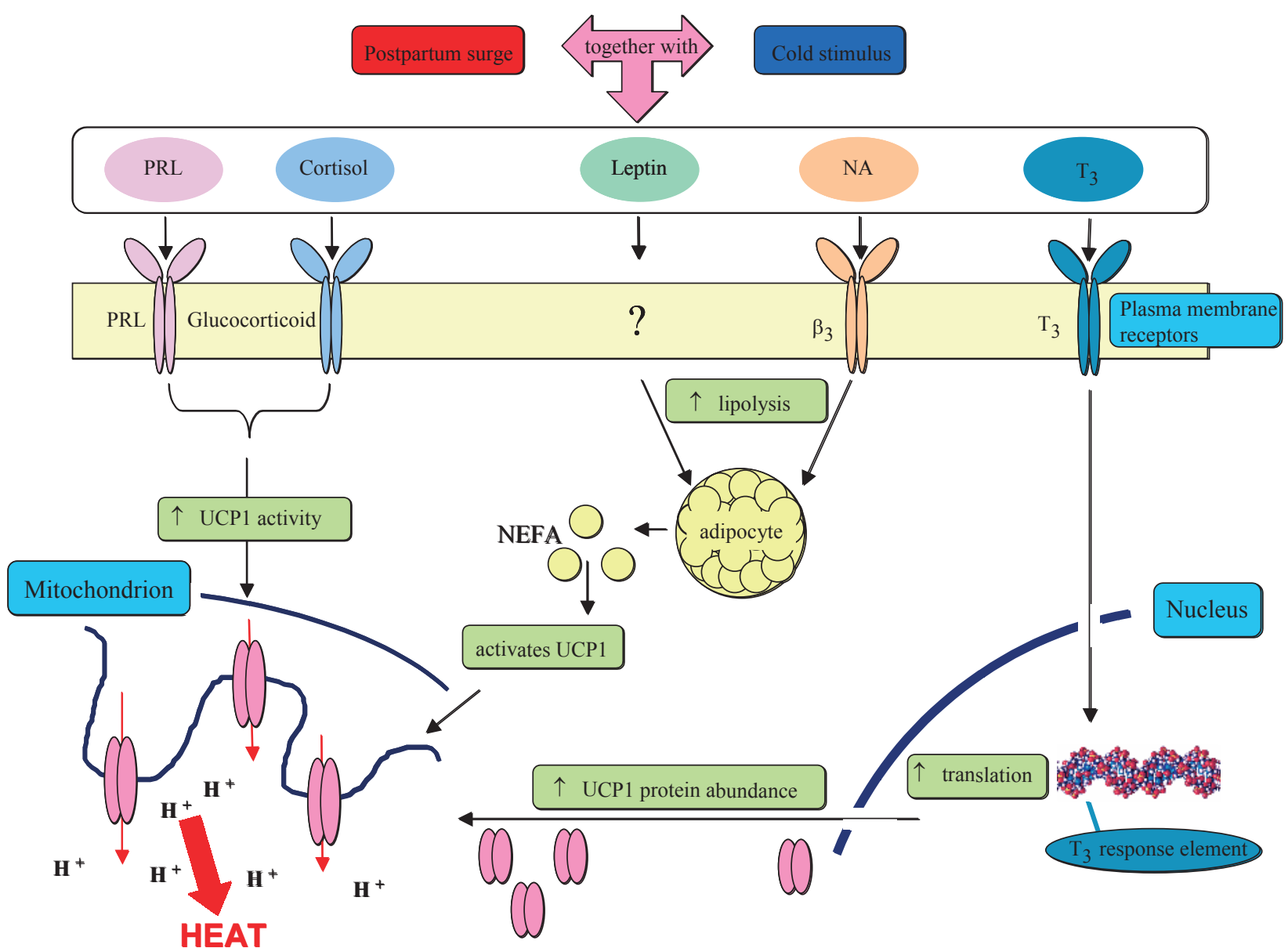

Figure 1 Summary of the endocrine regulation of fetal adipose tissue maturation in preparation for life after birth. PRL, prolactin; NA, noradrenaline; $\beta_{3}, \beta_{3}$-adrenergic receptor; NEFA, non-esterified fatty acids; $T_{3}$, triiodothyronine; UCP, uncoupling protein.

\section{Ontogeny of fetal adipose tissue}

The fetus grows and develops in an environment in which substrate availability is limited. Compared with the mother, the fetus is subjected to persistent hypoxia and hypoglycaemia. It is not therefore unexpected that as a consequence of the much higher metabolic demands for fat compared with protein deposition that fetal adipose tissue growth is much lower compared with after birth (Clarke et al. 1997b). Fetal fat possesses the dual characteristics of brown and white adipocytes (e.g. Casteilla et al. 1987, Devasker et al. 2002) from which leptin secretion may provide a 'lipostatic' role before birth (McMillen et al. 2004). In species such as humans and sheep that are born with a mature hypothalamic-pituitary axis and are precocial thermoregulators, brown fat abundance is maximal around the time of birth (Clarke et al. 1997a) and is then not normally detectable after the postnatal period (Lean 1989, Finn et al. 1998). For altricial species, such as rodents, in which the newborn maintain their body temperature by huddling together in a nest, maximal UCP1 abundance occurs postnatally coincident with maturation of the hypothalamic-pituitary axis (Cannon et al. 1988). Functional brown fat is then retained throughout the life cycle in rodents.

For humans and sheep, fetal adipose tissue deposition occurs primarily over the final third of gestation. In fetal sheep at least $80 \%$ of this fat is located around the kidneys (i.e. perirenal-abdominal adipose tissue) with very little, if any, fat present in the omental region which only develops after birth. During late gestation, as fetal fat mass expands, there is a concomitant increase in hormone receptor populations which, together with the development of the sympathetic nervous system, acts to ensure that UCP1 abundance peaks at birth (Symonds \& Stephenson 1999). The following adaptations, therefore, occur within adipose tissue during late gestation as summarised in Fig. 1:

1. Rise in sympathetic innervation (Gemmel \& Alexander 1972), $\beta$-adrenergic receptor density (Casteilla et al. 1994) and plasma catecholamine concentrations 
(Eliot et al. 1981), which are likely to be the primary stimulus for the initial appearance of UCP1.

2. Increase in plasma prolactin (Houghton et al. 1995) and prolactin receptor abundance (Symonds et al. 1998) that may directly stimulate further expression of UCP1.

3. Increase in plasma thyroid hormones (Fraser \& Liggins 1989) and enhanced capacity to convert thyroxine to the metabolically active tri-iodothyronine $\left(\mathrm{T}_{3}\right)$ via the enzyme 5'-monodeiodinase (Clarke et al. 1997a). This may result in a localised rise in $\mathrm{T}_{3}$ within the adipocyte that would be predicted to up-regulate and stabilise UCP1 expression (Stein et al. 1994, Guerra et al. 1996) and abundance (Heasman et al. 2000) via $\mathrm{T}_{3}$-responsive sequences on the UCP1 gene (Rabelo et al. 1995, Cassard-Doulcier et al. 1998).

The sensitivity of fetal adipose tissue to stimulation from endocrine factors appears to be greater than in the adult, when opposite effects can occur. For example, in the juvenile and adult rat, prolactin administration downregulates UCP1 abundance (Chan \& Swaminathan 1990, Pearce et al. 2003a) compared with up-regulation in the fetus (Budge et al. 2002). This distinct difference is likely to reflect the critical role of adipose tissue in the neonatal period as the newborn is subjected to physical and environmental stresses of an intensity seldom encountered again through life. The process of normal parturition at term, and concomitant squeezing through the birth canal, act to ensure maximal endocrine stimulation of the newborn (Clarke et al. 1997c). The peak in UCP1 on the inner mitochondrial membrane is accompanied by a high abundance of other mitochondrial proteins involved in energy metabolism (Mostyn et al. 2003b). These include voltage-dependent anion channel (VDAC), located on the outer mitochondrial membrane, which has a role in regulating the supply of mitochondrial ATP and ADP (Gottlieb 2000). VDAC abundance in fetal adipose tissue is not nearly as responsive to endocrine stimulation as UCP1 (Budge et al. 2002, Yuen et al. 2002, 2003, Mostyn et al. 2003a).

\section{Endocrine stimulation of fetal adipose tissue function}

During late gestation, a range of metabolic hormones have significant effects on fetal adipose tissue maturation. These roles have been established primarily in the sheep, which is arguably the optimum animal model for conducting this type of study. In the ovine fetus, therefore, specific endocrine manipulations have been shown to prematurely activate fetal UCP1. Chronic fetal infusion of the $\beta$-adrenergic receptor agonist ritodrine promotes the thermogenic potential of UCP1 and enhances lipolysis within the fetus (Bassett \& Symonds 1998). The same response is not observed when endogenous ligands of the adrenergic receptors, adrenaline and noradrenaline are infused, which could reflect greater receptor stimulation by synthetic agonists compared with the natural ligands. A 5-day period of continuous leptin infusion, sufficient to raise fetal plasma leptin five-fold, also results in raised UCP1 abundance, in conjunction with an increase in the proportion of multilocular compared with unilocular adipocytes whose size is reduced (Yuen et al. 2003). This is accompanied by a down-regulation of leptin mRNA abundance and could indicate that it is the relative size of an adipocyte which determines its capacity to synthesise leptin.

The adrenal gland is essential for the pre-partum rise in UCP1 (Mostyn et al. 2003a) but the extent to which cortisol alone, or in conjunction with parallel changes in plasma $T_{3}$, affects adipose tissue development remains to be established. An intact thyroid is necessary for the maximal appearance of UCP1 at birth (Schermer et al. 1996), with the weight of the thyroid gland being positively correlated with UCP1 abundance in the neonate. A compensatory fetal response to the lack of thyroid hormones and reduced UCP1 is an increase in lipid content of fat, indicating that these two characteristics of fetal adipose tissue can be inversely correlated.

Endocrine manipulation of the mother has also been shown to promote UCP1 maturation in the rat fetus. Prolactin administration throughout gestation to the mother which results in substantial transfer of prolactin into the fetus (Yang et al. 2002) promotes UCP1 abundance at the same time as reducing lipid locule size (Budge et al. 2002). Taken together, the above findings strongly suggest that an increased abundance of stimulatory endocrine factors are of greater importance in regulating fetal adipose tissue development than placental inhibitory factors such as adenosine and prostaglandin (Gunn \& Gluckman 1995). Placental factors have not been shown to have any direct maturational effects on UCP1 and only act to limit the rate of lipolysis (Gunn \& Gluckman 1995), which is not necessary for UCP1 expression (Mostyn et al. 2003a).

The post-partum surge in catecholamines and $T_{3}$ are critical for the maximal activation of UCP1 in the newborn (Symonds et al. 2000), but it has not been elucidated whether cortisol, prolactin or leptin can have similar roles. Both prolactin and leptin are able to elicit a transient thermoregulatory effect in the newborn (Mostyn et al. 2002, Pearce et al. 2003b), which acts to delay the decline in colonic temperature over the first 2 days of neonatal life. This response is mediated by an increase in the activity of pre-existing UCP1 rather than a further increase in UCP1 expression. Given the critical role that UCP1 has in preventing hypothermia in the newborn, particularly in sheep (Clarke et al. 1997c), it is not unexpected that a number of complementary control mechanisms act to ensure maximal recruitment. These may, however, be less efficient in preterm 


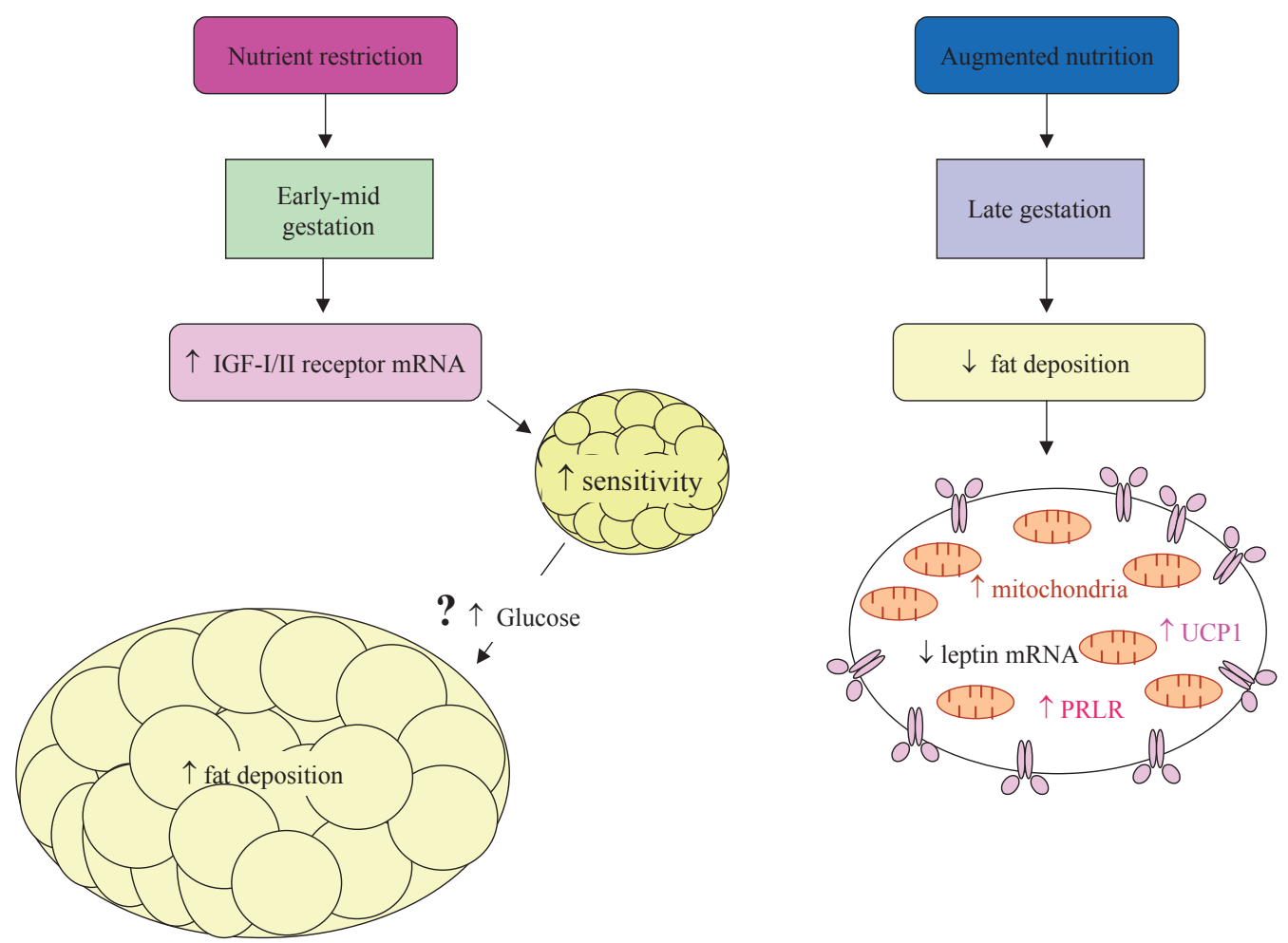

Figure 2 Summary of the differential effects of maternal nutritional manipulation of fetal adipose tissue growth. PRLR, prolactin receptor; IGF, insulin-like growth factor; UCP, uncoupling protein.

deliveries in which hormone receptor abundance can be reduced.

\section{Nutritional regulation of fetal adipose tissue deposition}

It is not only the abundance of UCP1 that is critical in determining heat production at birth - it is also the amount of fat (Symonds et al. 1992). Prolonged manipulation of maternal nutrition has pronounced effects on fetal adiposity (Fig. 2), which can occur in the absence of any change in the weight of other fetal organs (Budge et al. 2003). The consequences of maternal nutritional manipulation of the fetus with respect to fat deposition are strongly dependent on the time of the nutritional intervention. For sheep, maternal nutrient restriction between 28 and 80 days' gestation (term $=147$ days), which is coincident with the time of uterine attachment ( $\sim 28$ days) to the stage at which placental growth ceases ( $\sim 80$ days), has no initial effect on adipose tissue growth (Clarke et al. 1998). These fetuses do, however, subsequently deposit more adipose tissue up to term following the restoration of maternal diet to the same level as controls (Bispham et al. 2003). This adaptation is accompanied by an increased abundance of mRNA for insulin-like growth factors (IGF)-I and II receptors, which is likely to increase adipose tissue sensitivity to the potential anabolic effects of IGFs (Teruel et al. 1996). A combination of enhanced responsiveness to IGFs in conjunction with increased abundance of glucose to previously nutrient-restricted fetuses (Dandrea et al. 2001) may act to promote the anabolic effect of glucose on fetal fat deposition (Stevens et al. 1990). No effect was found on mitochondrial protein abundance, suggesting a divergence of endocrine control between adipose tissue deposition and functional consequences in terms of UCP1 expression. An increase in the amount of adipose tissue alone would, however, be sufficient to promote total UCP1 abundance in the newborn.

Surprisingly, increasing maternal nutrition in late gestation can have reciprocal effects on adipose tissue deposition and UCP1 abundance. When maternal food intake is unrestricted, this results in proportionately less adipose tissue per kilogram of fetus but increased UCP1 abundance (Budge et al. 2000). At the same time there is an inverse relationship between mRNA for UCP1 and leptin in adipose tissue samples from well-fed, but not control, fetuses (Mühlhäusler et al. 2003) suggesting a change in both brown and white adipocyte characteristics 
with increased nutrition. These adaptations may reflect the modest rise in both fetal plasma glucose and insulin in well-fed animals, although these were not of sufficient magnitude to promote fat deposition. Raised maternal food intake also results in higher fetal plasma prolactin (Stephenson et al. 2001) in conjunction with increased abundance of the long, but not short, form of the prolactin receptor (Budge et al. 2000). The long and short forms of prolactin receptor result from differential splicing of a single gene transcript (Bignon et al. 1997) and although these splice variants differ in their intracellular signalling regions they have identical extracellular domains. Nutritional enhancement of the long form of the prolactin receptor, in conjunction with raised prolactin, may be important in promoting UCP1 abundance in the fetus (Budge et al. 2000, 2002).

Reduced maternal nutrition in late gestation results in smaller fat depots with less UCP1 (Symonds et al. 1998, Budge et al. 2001), in conjunction with lower fetal plasma glucose and insulin, but has no effect of fetal leptin or prolactin receptor mRNA abundance (Symonds et al. 1998, Yuen et al. 2002). After birth, however, there appears to be a compensatory increase in VDAC abundance in nutrient-restricted offspring (Budge et al. 2003) that is maintained up to at least 1 month of age (Mostyn et al. 2003b). This is accompanied by an increase in UCP2, which, in contrast to UCP1, only appears to be present after birth. A higher abundance of UCP2 may have adverse consequences as this can result in enhanced susceptibility to infection and death from toxoplasmosis (Arsenijevic et al. 2000). It has also been shown that in obese women UCP2 gene exon 8 may affect susceptibility to obesity through an interaction with leptin (Cassell et al. 1999). Enhanced abundance of both UCP2 and VDAC could result in an accelerated rate of apoptosis (Voehringer et al. 2000). Clearly, the longer-term consequences of these different nutritional models of adipose tissue manipulation need to be established.

In conclusion, fetal adipose tissue growth is a coordinated process that involves the accumulation of lipid and synthesis of the brown adipose tissue specific UCP1. In species with a mature hypothalamic-pituitary axis, a major end point of endocrine regulation is to maximise UCP1 synthesis that can then be activated rapidly at birth to ensure effective adaptation to cold exposure of the extra-uterine environment. The apparent nutritional sensitivity of adipose tissue growth to both increased and decreased maternal nutrition may not only have consequences in the immediate peri-partum period but could persist into later life.

\section{Funding}

Biotechnology and Biological Sciences Research Council and Special Trustees for Nottingham University Hospitals.

\section{References}

Arsenijevic D, Onuma H, Pecquer C, Raimbault S, Manning BS, Miroux B, Couplan E, Alves-Guerra M-C, Goubern M, Surwit R, Bouillaud F, Richard D, Collins S \& Ricquier D 2000 Disruption of the uncoupling protein-2 gene in mice reveals a role in immunity and reactive oxygen species production. Nature Genetics 26 435-439.

Bassett JM \& Symonds ME $1998 \beta_{2}$-Agonist ritodrine, unlike natural catecholamines, activates thermogenesis prematurely in utero in fetal sheep. American Journal of Physiology 275, R112-R119.

Bignon C, Binart N, Ormandy C, Schuler LA, Kelly PA \& Dijane J 1997 Long and short forms of the ovine prolactin receptor: cDNA cloning and genomic analysis reveal that the two forms arise by different alternative splicing mechanisms in ruminants and rodents. Journal of Molecular Endocrinology 19 109-120.

Bispham J, Budge H, Mostyn A, Dandrea J, Clarke L, Keisler D, Symonds ME \& Stephenson T 2002 Ambient temperature, maternal dexamethasone, and postnatal ontogeny of leptin in the neonatal lamb. Pediatric Research 52 85-90.

Bispham J, Gopalakrishnan GS, Dandrea J, Wilson V, Budge H, Keisler DH, Broughton Pipkin F, Stephenson T \& Symonds ME 2003 Maternal endocrine adaptation throughout pregnancy to nutritional manipulation: consequences for maternal plasma leptin and cortisol and the programming of fetal adipose tissue development. Endocrinology 144 3575-3585.

Budge H, Bispham J, Dandrea J, Evans L, Heasman L, Ingleton P, Sullivan C, Wilson V, Stephenson T \& Symonds ME 2000 Effect of maternal nutrition on brown adipose tissue and prolactin receptor status in the fetal lamb. Pediatric Research 47 781-786.

Budge H, Edwards L, Stephenson T, Symonds ME \& McMillen IC 2001 Effects of maternal nutrient restriction on ovine fetal uncoupling protein 1 expression. Biochemical Society Transactions 29 51.

Budge H, Mostyn A, Wilson V, Khong A, Walker AM, Symonds ME \& Stephenson T 2002 The effect of maternal prolactin infusion during pregnancy on fetal adipose tissue development. Journal of Endocrinology 147 427-433.

Budge H, Dandrea J, Mostyn A, Evens Y, Watkins R, Sullivan C, Ingleton P, Stephenson T \& Symonds ME 2003 Differential effects of fetal number and maternal nutrition in late gestation on prolactin receptor abundance and adipose tissue development in the neonatal lamb. Pediatric Research 53 302-308.

Cannon B, Connoley E, Obregon M-J \& Nedergaard J 1988 Perinatal activation of brown adipose tissue. In The Endocrine Control of the Fetus, pp 306-320. Eds W. Kunzel \& A. Jesen. Berlin: Springer Verlag.

Cassard-Doulcier A, Gelly C, Bouillaud F \& Ricquier D 1998 A 211-bp enhancer of the rat uncoupling protein-1 (UCP-1) gene control specific and regulated expression in brown adipose tissue. Biochemical Journal 333 243-246.

Cassell PG, Neverova M, Janmohamed S, Uwakwe N, Qureshi A, McCarthy MI, Saker PJ, Albon L, Kopelman P, Noonan K, Easlick J, Ramachandran A, Snehalatha C, Pecqueur C, Ricquier D, Warden C \& Hitman GA (1999) An uncoupling protein 2 gene variant is associated with a raised body mass index but not Type II diabetes. Diabetologia 42 688-692.

Casteilla L, Forest C, Robelin J, Ricquier D, Lombert A \& Ailand G 1987 Characterisation of mitochondrial-uncoupling protein in bovine fetus and newborn calf. American Journal of Physiology 254 E627-E636.

Casteilla L, Champigny O, Muzzin P, Bouillaud F, Robelin J \& Ricquier D 1994 Expression of $\beta_{1}$ - and $\beta_{3}$-adrenergic-receptor messages and adenylate cyclase $\beta$-adrenergic response in bovine perirenal adipose tissue during its transformation from brown into white fat. Biochemical Journal 297 93-97. 
Chan E \& Swaminathan R 1990 Role of prolactin in lactationinduced changes in brown adipose tissue. American Journal of Physiology 258 R51-R56.

Clarke L, Bryant MJ, Lomax MA \& Symonds ME 1997a Maternal manipulation of brown adipose tissue and liver development in the ovine fetus during late gestation. British Journal of Nutrition 77 871-883.

Clarke L, Buss DS, Juniper DS, Lomax MA \& Symonds ME 19976 Adipose tissue development during early postnatal life in ewereared lambs. Experimental Physiology 82 1015-1017.

Clarke L, Heasman L, Firth K \& Symonds ME 1997c Influence of route of delivery and ambient temperature on thermoregulation in newborn lambs. American Journal of Physiology 272 R1931R1939.

Clarke L, Heasman L, Juniper DT \& Symonds ME 1998 Maternal nutrition in early-mid gestation and placental size in sheep. British Journal of Nutrition 79 359-364.

Dandrea J, Wilson V, Gopalakrishnan G, Heasman L, Budge H, Stephenson T \& Symonds ME 2001 Maternal nutritional manipulation of placental growth and glucose transporter-1 abundance in sheep. Reproduction 122 793-800.

Devasker SU, Anthony RV \& Hay WW 2002 Ontogeny and insulin regulation of fetal ovine white adipose tissue leptin expression. American Journal of Physiology 282 R431-R438.

Eliot RJ, Klein AH, Glatz TH, Nathanielsz PW \& Fisher DA 1981 Plasma norepinephrine, epinephrine and dopamine concentrations in maternal and fetal sheep during spontaneous parturition and in premature sheep during cortisol-induced parturition. Endocrinology 108 1678-1682.

Finn D, Lomax MA \& Trayhurn P 1998 An immunohistochemical and in situ hybridisation study of the postnatal development of uncoupling protein-1 and uncoupling protein-1 mRNA in lamb perirenal adipose tissue. Cell Tissue Research 294 461-466.

Fraser M \& Liggins GC 1989 The effect of cortisol on thyroid hormone kinetics in the ovine fetus. Journal of Developmental Physiology 11 207-211.

Gemmel RT \& Alexander G 1972 Ultrastructural development of adipose tissue in foetal sheep. Australian Journal of Biological Sciences 31 505-515.

Gottlieb RA 2000 Mitochondria: execution central. FEBS Letters 482 6-12.

Guerra C, Roncero C, Porras A, Fernandez M \& Benito M 1996 Triiodothyronine induces the transcription of the uncoupling protein gene and stabilizes its mRNA in fetal rat brown adipocyte primary cultures. Journal of Biological Chemistry 271 2076-2081.

Gunn T \& Gluckman PD 1995 Perinatal thermogenesis. Early Human Development 42 169-183.

Heasman L, Clarke L \& Symonds ME 2000 Influence of thyrotropin-releasing hormone administration at birth on thermoregulation in lambs delivered by cesarean. American Journal of Obstetrics and Gynecology 183 1257-1262.

Houghton DC, Young IR \& McMillen IC 1995 Response of prolactin to different photoperiods after surgical disconnection of the hypothalamus and pituitary in sheep fetuses. Journal of Reproduction and Fertility 104 199-206.

Lean MEJ 1989 Brown adipose tissue in humans. Proceedings of the Nutrition Society 48 243-256.

McMillen IC, Muhlhäusler BS, Duffield JA \& Yuen BS 2004 Prenatal programming of postnatal obesity: fetal nutrition and the regulation of leptin synthesis and secretion before birth. Proceedings of the Nutrition Society (In Press).

Mostyn A, Bispham J, Pearce S, Evens Y, Raver N, Keisler DH, Webb R, Stephenson T \& Symonds ME 2002 Differential effects of leptin on thermoregulation and uncoupling protein abundance in the neonatal lamb. FASEB Journal 16 1438-1440.
Mostyn A, Pearce S, Budge H, Elmes M, Forehead AJ, Fowden AL, Symonds ME \& Stephenson T 2003a Influence of cortisol on adipose tissue development in the fetal sheep during late gestation. Journal of Endocrinology 176 23-30.

Mostyn A, Wilson V, Dandrea J, Yakubu DP, Budge H, Alves-Guerra MC, Pecqueur C, Miroux B, Symonds ME \& Stephenson T 2003b Ontogeny and nutritional manipulation of mitochondrial protein abundance in adipose tissue and the lungs of postnatal sheep. British Journal of Nutrition 90 323-328.

Mühlhäusler BS, Roberts CT, Yuen BSJ, Marrocco E, Budge H, Symonds ME, McFarlane JR, Kauter KG, Stagg P, Pearse JK \& McMillen IC 2003 Determinants of fetal leptin synthesis, fat mass and circulating leptin concentrations in well nourished ewes in late pregnancy. Endocrinology (In Press).

Pearce S, Casteilla L, Gualillo O, Symonds ME \& Stephenson T 2003a Differential effects of age and gender on the postnatal responsiveness of brown adipose tissue to prolactin administration in rats. Experimental Physiology 88 527-531.

Pearce S, Mostyn A, Alves-Guerra MC, Pecqueur C, Miroux B, Webb R, Stephenson T \& Symonds ME $2003 b$ Prolactin receptor (PRLR) and uncoupling proteins (UCPs) during fetal and neonatal development. Proceedings of the Nutrition Society 62 421-427.

Power G 1989 Biology of temperature: the mammalian fetus. Journal of Developmental Physiology 12 295-304.

Rabelo R, Schifman A, Rubio A, Sheng X \& Silva JE 1995 Delineation of thyroid hormone-responsive sequences within a critical enhancer in the rat uncoupling protein gene. Endocrinology 136 1003-1013.

Schermer SJ, Bird JA, Lomax MA, Shepherd DAL \& Symonds ME 1996 Effect of fetal thyroidectomy on brown adipose tissue and thermoregulation in newborn lambs. Reproduction, Fertility, and Development 8 995-1002.

Stein HM, Martinez A, Blount L, Oyama K \& Padbury JF 1994 The effects of corticosteroids and thyrotropin-releasing hormone on newborn adaptation and sympathoadrenal mechanisms in preterm sheep. American Journal of Obstetrics and Gynaecology 171 17-24.

Stephenson T, Budge H, Mostyn A, Pearce S, Webb R \& Symonds ME 2001 Fetal and neonatal adipose tissue maturation: a primary site of cytokine and cytokine-receptor action. Biochemical Society Transactions 29 80-85.

Stevens D, Alexander G \& Bell AW 1990 Effects of prolonged glucose infusion into fetal sheep on body growth, fat deposition and gestation length. Journal of Developmental Physiology 13 277-281.

Symonds ME \& Lomax MA 1992 Maternal and environmental influences on thermoregulation in the neonate. Proceedings of the Nutrition Society 51 165-172.

Symonds ME \& Stephenson T 1999 Maternal nutrient restriction and endocrine programming of fetal adipose tissue development. Biochemical Society Transactions 27 97-103.

Symonds ME, Bryant MJ, Clarke L, Darby CJ \& Lomax MA 1992 Effect of maternal cold exposure on brown adipose tissue and thermoregenesis in the neonatal lamb. Journal of Physiology 455 487-502.

Symonds ME, Phillips ID, Anthony RV, Owens JA \& McMillen IC 1998 Prolactin receptor gene expression and foetal adipose tissue. Journal of Neuroendocrinology 10 885-890.

Symonds ME, Bird JA, Sullivan C, Wilson V, Clarke L \& Stephenson T 2000 Effect of delivery temperature on endocrine stimulation of thermoregulation in lambs born by cesarean section. Journal of Applied Physiology 88 47-53.

Teruel T, Valverde AM, Benito M \& Lorenzo M 1996 Insulin-like growth factor and insulin induce adipogenic-related gene expression in fetal brown adipocyte primary cultures. Biochemical Journal 319 627-632.

Voehringer DW, Hirschberg DL, Xiao J, Lu Q, Roederer M, Lock CB, Herzenberg LA, Steinman L \& Herzenberg LA 2000 Gene microarray identification of redox and mitochondrial elements that control resistance or sensitivity to apoptosis. PNAS 97 2680-2685. 
Yang L, Lii S, Kuo B, Buckley A, Buckley D, Chen C, Xu X, Coss D \& Walker AM 2002 Maternal prolactin composition can permanently affect epidermal $\gamma \delta \mathrm{T}$ cell function in the offspring. Developmental and Comparative Immunology 26 849-860.

Yuen BSJ, Owens PC, McFarlane J, Symonds ME, Edwards LJ, Kauter KG \& McMillen IC 2002 Circulating leptin concentrations are positively related to leptin mRNA expression in fetus adipose tissue in the pregnant ewe fed at or below maintenance energy requirements during late gestation. Biology of Reproduction $\mathbf{6 7}$ 911-916.
Yuen BS, Owens PC, Muhlhäusler BS, Roberts CT, Symonds ME, Keisler DH, McFarlane JR, Kauter KG, Evens Y \& McMillen IC 2003 Leptin alters the structural and functional characteristics of adipose tissue before birth. FASEB Journal 17 1102-1104.

Received 22 August 2003

Accepted 28 August 2003

Made available online as an

Accepted Preprint 8 September 2003 